\title{
E-VOTING AS A NEW FORM OF CIVIC PARTICIPATION IN DEMOCRATIC PROCEDURES
}

\author{
by Magdalena Musiat-Karg
}

\section{INTRODUCTION}

Times are changing. The second half of the $19^{\text {th }}$ century and the following years stood for rapid development of various tools based on electricity. Expansion of telecommunication and progress of electronic media constitute important elements of this period. It may be said, we now live in the Internet era, and there is a perception that anyone who does not jump on the technology bandwagon is going to be left far behind. ${ }^{1}$ The growth of online interactions can be observed by the inconceivable increase in the number of people with home PC and Internet access.

Information revolution, that is a rapid technological development within the scope of computers, communication processes and software (involving substantial decrease in the costs of processing and sharing information) is the driving force behind globalisation. ${ }^{2}$ Recent worldwide convergence

1 A. Rubin, Security Considerations for Remote Electronic Voting over the Internet, http://avirubin.com/ (10.02.2010).

2 R. Keohane, J. Nye, Power and Interdependence in the Information Age, [in:] Democracy.com? Governence in a Networked World, E. Kamarck, J. Nye (eds.), Hollis 1999, p. 200. 
of information and communication technologies (ICT) lead to evident changes in running of contemporary nation states and their societies. As a consequence, almost all fields of human activities remain significantly influenced by modern technologies. Today people have an easy access to information, what is a consequence of development of the Internet, television and mobile communications. This availability information of affects millions of human beings in the world, and also changes the rules of social life in broader perspective. ${ }^{3}$ Currently, ICT begin to play greater role and filter down to almost every sphere of contemporary people becoming a very popular subject of concern. Moreover, modern technologies have evolved so much, and continue to grow, that they became an interesting, and absorbing a lot of attention, topic of academic inquiries. Increasingly, the social consequences of the information revolution are discussed and debated not only by many scientists, but also by many politicians, administration workers, businessmen, and journalists. Wide access to information (which is much greater thanks to ICT) is becoming increasingly important in social, economical and political life. The proof of it is undoubtedly the emergence and use of concepts such as e-society, e-banking, e-services, e-government, e-government and e-democracy.

The newly used word e-democracy is an evidence that modern technologies have been also widely used in politics. In this context one should bear in mind that practically in most countries politicians, political parties and those working in political institutions or administration seek to employ and use new technologies in the processes of information and communication with the electorate. They aim to implement ICT to the processes of transmitting and obtaining information. In addition, in many modern countries traditional methods of voting are supplemented with new solutions based on the use of electronic tools.

Thus, the political actors use ICT in three main processes in the political market ${ }^{4}$, namely in information, communication and voting procedures. The main subject of this text is to analyze the electronic voting

\footnotetext{
${ }^{3}$ L. Porębski, Elektroniczne oblicze polityki. Demokracja, państwo, instytucje polityczne w okresie rewolucji informacyjnej, Kraków 2004, p. 9.

4 Political market is a communication space in which political parties and institutions inform electorate about their activities through mass media; M. Cichosz, Metody
} 
(e-voting) as one of the forms of electronic democracy. The article attempts to answer the following research questions: First, what is the impact of ICT on the political processes in the political market - particularly on the voting procedures? Secondly, what is the essence of electronic voting and what are its main features? Finally, what are the advantages and concerns related to the e-voting systems? Theoretical considerations are based mainly on the concept of electronic democracy constructed by Martin Hagen, while in the final part some European experiences related to the use of e-voting are mentioned.

\section{E-DEMOCRACY}

Swift progress and expansion of the ICT influences contemporary societies, hence changing the character of interpersonal relationships, way of communication, going in for politics and contributes to creation of a new quality of social life. Information and Communication Technologies have become a tool for politics. The role of ICT gained such an importance that some theoreticians of democracy see the necessity of changing paradigm of understanding democratic system and introducing a notion of electronic democracy (e-democracy). ${ }^{5}$ The concept of $e$-democracy is related to the utilization of technology to increase participation in exercising the power. Some of the first deliberations on the links between new technologies and democracy reflected the potential of telecommunications, with particular emphasis on cable TV and telephone. ${ }^{6}$ Today the main

analizy i diagnostyki rynku politycznego, [in:] Marketing polityczny $w$ teorii i praktyce, A. Jabłoński, L. Sobkowiak (eds.), Wrocław 2002, pp. 91, 93.

5 B.N. Hague, B. Loader, Digital Democracy: Discourse and Decision-making in the Information Age, New York 1999.

6 T. Carrizales, Critical Factors in an Electronic Democracy: a Study of Municipal Managers, “The Electronic Journal of e-Government” 2008, Issue 1, Vol. 6, p. 24, http:// www.ejeg.com/volume-6/vol6-iss1/Carrizales.pdf (27.02.2010); F. C. Arterton, Political Participation and Teledemocracy, "Political Science and Politics" 1988, No. 3, Vol. 21, pp. 620-626; T.L. Becker, C.D. Slaton, The Future of Teledemocracy, Westport, CT 2000. 
focus has shifted to the Internet whose role is growing rapidly.7 ICTs now make it possible for citizens to participate in the process of creation of public life. Increased access to information and to political debate, online political discussions and new additional form if voting (e-voting) are the main aspects of electronic democracy. Such an electronic republic may be a great "opportunity for citizens to elect representatives, while increasingly being able to participate in law making. ${ }^{8}$

In social studies there is no agreement how to understand the term electronic democracy, thus there is no uniform definition. It is worth, though, presenting couple of explanations which seem to be the most distinctive and accurate for proper understanding of the term. In the document titled Inquiry into Electronic Democracy. Final Report by Australian Parliament of Victoria Electronic democracy is defined as: "The use of information communications technologies by individuals to extend their choices for thinking and acting as citizens, unrestricted by time and place, and culminating in greater collective freedom under the rule of law."

Issues related to electronic democracy are examined also by Polish scholars (e.g. M. Grabowska, T. Szawiel, A. Kaczmarczyk, M. Sakowicz, M. Nowina-Konopka). According to definition presented by Andrzej Kaczmarczyk and Roman Czajkowski, electronic democracy may be understood as a set of processes that are realized through electronic media from the beginning of the emergence of civil concept and the formulation of suggestions until their final implementation of it. This set encompasses researching activities, planning, implementation and management (making decisions, taking control, information, communication and more). The authors maintain that thanks to information society a new model of democracy will be created. E-democracy will be based on the application of information and communication. ${ }^{10}$

\footnotetext{
7 T. Carrizales, Critical Factors..., p. 24.

8 L.K. Grossman, The Electronic Republic: Reshaping Democracy in the Information Age. New York 1995.

9 Inquiry into Electronic Democracy. Final Report, Parliament of Victoria, Australia, Scrutiny of Acts and Regulations Committee, 2003, s. xliv; http://www.parliament.vic. gov.au/SARC/E-Democracy/Final_Report/Final_Report.pdf (25.11.2009).

10 A. Kaczmarczyk, R. Czajkowski, E-Głosowanie - niezbędny element elektronicznej
} 
According to Martin Hagen „an Electronic Democracy is any democratic political system in which computers and computer networks are used to carry out crucial functions of the democratic process - such as information and communication, interest articulation and aggregation, and decision-making (both deliberation and voting)." 11 Hagen lists three various concepts of electronic democracy: teledemocracy, cyberdemocracy and electronic democracy.

Teledemocracy developed in the 1970s was designed to introduce additional forms of direct democracy within American political system and implement them using new communication technologies. Whereas the concept of teledemocracy emerged as a result of the cable television development, cyberdemocracy based on the evolution of computer networks. Unlike teledemocracy and cyberdemocracy, electronic democratization does not aim at establishing direct forms of democracy but at improving the representative democracy. ${ }^{12}$ Hagen understands electronic democratization as a form of development and reinforcement of democracy which uses new communication technologies to strengthen political power of those who are often omitted in the most important political processes. ${ }^{13}$ The electronic democratization goes in line with representative forms of democracy and emphasizes the value of information exchanges and political discussions for citizens involvement in the political sphere.

Taking into account structure of the political market one may list three main processes that happen there: informing, communicating and voting. Besides their traditional dimension the development of new technologies contributed to the emergence of new ways of those practices. The growth of online interaction and presence can be witnessed by the exponential

platformy do obstugi procedur w demokracji w społeczeństwie informacyjnym. E-vote - an essential element of electronic platform for services for democratic procedures in the Information Society, a paper presented on a conference entitled „Tworzenie mechanizmów i struktur rozwoju elektronicznej gospodarki w Polsce", Warszawa, 12.06.2001, p. 48; http://www.logistyka.net.pl/images/articles/1375/Ref-Czajkowski.doc, (13.11.2009).

11 M. Hagen, A Typology of Electronic Democracy, 1997, http://www.uni-giessen.de/ $\mathrm{fb} 03 /$ vinci/labore/netz/hag_en.htm, (12.02.2010).

12 Ibidem.

13 K.L. Hacker, M.Todino, Virtual Democracy at the Clinton White House: An Experiment in Electronic Democratisation, "javnost/the public" 1996, No. 1, Vol. 3, p. 72. 
increase in the number of people with home computers and Internet access. ${ }^{14}$ ICT, and most of all the Internet, influence democratic processes thus supplement, quicken and facilitate the processes of: sharing information, involvement in political debate and participation in political decisionmaking. ${ }^{15}$

\section{E-VOTING}

The third process in the political market and also the subject of considerations in this article is voting. Elections offer those eligible to vote the possibility to opt for their favorite representatives in the parliament chambers or the right to express their opinion on an issue which is a subject of popular vote. Applying of ICT in the voting process has a potential to overcome barriers which hinder or limit the electorate to take part in decision-making processes. One should remember that electronic voting is not the same as electronic democracy. E-democracy and e-voting are noticeably different technological fields.

E-democracy is related to making use of the opportunities that ICT offer in order to strengthen democracy, democratic institutions and the democratic process. ${ }^{16}$ Of all the e-democratic devices, particularly electronic voting is getting more and more attention worldwide. Politicians and authorities of many countries are interested in e-voting possibilities and conduct experiments to introduce new form of voting. What is more societies in more and more countries are eager to make use of electronic way of expressing their opinions in voting procedures. ${ }^{17}$

\footnotetext{
14 A. Rubin, Security Considerations..., p. 1.

15 R. Tsagarousianou, Electronic democracy: Rhetoric and reality, Communications, "The European Journal of Communication Research" 1999, No. 2, Vol. 24, pp. 189-208.

16 Council of Europe activities in the field of e-democracy, http://www.coe.int/t/dgap/ democracy/Activities/GGIS/CAHDE/Default_en.asp, (15.02.2010).

17 In the Netherlands, $62 \%$ of the people with access to the Internet would prefer to vote online; W. Pieters, M.J. Becker, Ethics of e-voting. An essay on requirements and values in Internet elections, http://www.win.tue.nl/ipa/archive/falldays2005/Paper_Pieters. pdf, (15.02.2010).
} 
Undubtedly, electronic voting is the subject of increasing interest of public administration institutions, parliaments, governments, political parties, politicians, academics or journalists. Moreover, e-voting seems to be gaining more and more importance and begins to be one of the primary instruments of $e$-democracy. Many researchers working on processes based on applications of new technologies in politics assert that in the future citizen's rights and duties would be realized with the use of information and communication technologies. The essential element of such expansion would be the electronic voting which is currently implemented in an increasing number of countries.

According to definition by Czajkowski and Kaczmarczyk, "electronic voting [...] is the act of voting with the use of electronic means. Electronic voting comprises computer voting - which in turn comprises online voting, and internet voting which requires computer with an access to the Internet." 18

There is an obvious lack of terminological discipline in literature, with regard to the differentiation of voting forms that use ICT (information and communication technologies). According to another definition - electronic voting (e-voting) is an election system that allows an eligible voter to record his or her secure and secret ballot electronically. E-voting is a term encompassing several different types of voting, embracing both electronic means of casting a vote and electronic means of counting votes. Electronic voting technology can include punch cards, optical scan voting systems and specialized voting kiosks. It can also involve transmission of ballots and votes via telephones, private computer networks, or the Internet. ${ }^{19}$

In a discussion on the new ways of citizen's participation in democratic procedures two types of voting are usually mentioned: electronic voting (e-voting) and internet voting ( $i$-voting). While $e$-voting is a term of broader meaning and includes other electronic voting techniques, $i$-voting is just one of its forms and refers to remote voting with a computer via the Internet. It needs to be said that many observers and commentators of

\footnotetext{
18 A. Kaczmarczyk, R. Czajkowski, E-Głosowanie - niezbędny element..., pp. 47, 50.

19 Advertt.com. Adverrt English Dictionary, http://advertt.com/definition/meaningof-electronic-voting, (14.02.2010).
} 
Diagram 1. Electronic voting and its forms

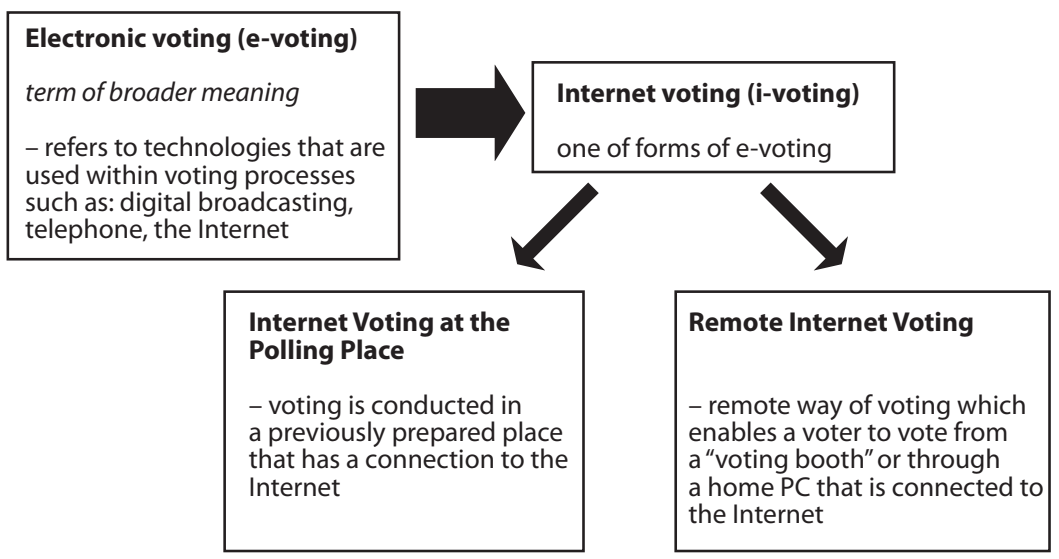

Source: the current author's study based also on M. Nowina-Konopka, 2006.

public life are generally optimistic about the potential possibilities of $i$-voting. It seems that advocates of $i$-voting believe that it has the potential to solve the currently noticeable problem of low voter turnout by providing a more convenient option. Opponents of $i$-voting argue that the biggest challenge of i-voting systems is the security risk and that " $i$-voting will disproportionately benefit certain groups based on race and economic status." 20

The term electronic voting refers to technologies that are used within voting processes such as: digital broadcasting, telephony, the Internet. ${ }^{21}$ Internet voting is divided into two categories: Internet Voting at the Polling Place and Remote Internet Voting. The first one is based on voting conducted in a previously prepared place that has a connection to the Internet, and the second form is a remote way of voting which enables a voter to vote from a "voting booth" or through a home PC that is connected to the Internet. Data, both from a booth and a PC, is transmitted online to, central database.

20 B. Stohs, Is i-voting illegal?, p. 2, http://www.law.duke.edu/journals/dltr/articles/ pdf/2003DLTR0013.pdf, (15.02.2010).

21 M. Nowina-Konopka, Elektroniczna urna, 2006, p. 2, http://www.rpo.gov.pl/pliki/ 12066058070.pdf, (11.02.2010). 
From the technical point of view, e-voting systems consist of six main stages. The first one is voters' registration, which is a phase aimed to define voters for the e-voting system and give them authentication data to log into the system. The second phase is authentication. It is based on verification whether the voters have the access to rights and franchise. After authentication phase the voting and the votes' saving stage take place. In this phase eligible voters cast votes and e-voting system saves the received votes from voters. The votes' managing phase is a process, in which votes are first managed, then sorted and prepared for counting. The fifth phase - votes' counting - is to decrypt and count the votes, and output the final tally. The last stage of electronic voting is auditing, which is based on checking that those eligible voters were capable of voting and their votes participate in the computation of final tally.22

\section{ADVANTAGES OF ELECTRONIC VOTING}

Before assessing the possible role and experiences of electronic voting, we must consider why e-voting systems may be attractive and why they cause concern. While not exhaustive, the following section summarizes some of the significant issues raised by electoral authorities, administration officers or politicians with respect to electronic voting.

There is no doubt that popularity of electronic voting is growing mainly because it is a novel concept to hundreds of millions of people worldwide and because many voters prefer $e$-voting (in particular online voting) to any other method. ${ }^{23}$

Enabling citizens to vote and decide directly about important matters which concern their society and condition of their country is the heart of democracy. ${ }^{24}$ It should be emphasized in this place that electronic voting

22 T. Mägi, Practical Security Analysis of E-voting Systems, Tallin 2007, p. 16, http:// triinu.net/e-voting/master\%20thesis\%20e-voting\%20security.pdf (15.02.2010).

23 The I's Have It, http://www.everyonecounts.com/index.php/why_everyone_counts/ why_i-voting (14.02.2010).

24 S. Grabowska, Instytucja ogólnokrajowej inicjatywy ludowej w wybranych państwach europejskich. Studium prawno-porównawcze, Rzeszów 2005, p. 18. 
is not intended to replace the traditional way of voting. The primary purpose of employing ICT is providing alternative to increase accessibility to the voting process for a wider variety of citizens, including the disabled, those living or working abroad or in remote areas and for immigrant citizens. ${ }^{25}$

Electronic voting systems may offer advantages compared to other voting techniques. Focusing on voting procedures, one may state that the new technologies' revolution affected election management in a number of ways. ${ }^{26}$ The most important benefit of e-voting is that it can be involved in any one of a number of steps in the setup, distributing, voting, collecting, and counting of ballots. "Electoral authorities use computer systems to make their internal management and communications more effective, to systematize voter registration records, and to communicate with voters, among other tasks."27

Proponents of electronic way of voting have argued that it could increase voter turnout, because it makes voting possible for the disabled people or for those who are abroad. E-voting is more convenient than traditional voting at the polling station - there is no longer need to leave home and travel to a given institution, no need to wait in queues. This new form of casting votes may be a very profitable if it comes to the turnout. E-voting influence the participation level because it may appeal to younger voters (among whom voter turnout has tended to be particularly low). What is more, many supporters state that electronic voting (in particular online voting) could allow more information to be displayed about candidates, their political programs and policies. However, one should bear in mind that it "would be in conflict with existing laws about not campaigning in the immediate vicinity of a polling place and would need to be strictly supervised." 28 Electronic voting can be also a very beneficial

\footnotetext{
25 The I's Have It..., op.cit.

26 J. Blanc, Challenging the Norms and Standards of Election Administration: Electronic Voting, [in:] Challenging the Norms and Standards of Election Administration, IFES 2007, p. 11.

27 Ibidem.

28 Online Voting, Parliamentary Office of Science and Technology, Postnote No. 155/2001, p. 3, http://www.parliament.uk/post/pn155.pdf (11.02.2010).
} 
device because of the costs. In the long term it may reduce expenses involved in setting up and staffing poll sites. It needs to be emphasized that in the initial phase of the voting arrangements - e-voting may generate relatively high expenditures on the new system infrastructure.

\section{CONCERNS ABOUT ELECTRONIC VOTING}

The process of introduction of the new forms of democratic procedures has provoked a discussion on the weak sides of e-voting. Even though societies widely apply modern technologies (mainly the Internet) into business, work or education, governments and legislative bodies, politicians, experts and academic in many countries are still self-restraint with using ICT in voting procedures. One of the examples of it, is that several countries have expressed concern over the possibility that electronic voting can lead to massive electoral fraud. Another issue is related to the transparency of the election process, since "all processes of data generation, transformation, and storage occur in 'black boxes' that are often not fully transparent even for technical experts." 29 That is why, electronic voting system is sometimes called a 'black box' - voters, candidates and even officials cannot see how the machines work from the iside. Only a small group of technologists (administrator of the systems) and other experts have any idea about the way the voting is conducted or counted. Many opponents of the e-vote while discussing pros and cons of it, ask question whether voters would trust a computer? Additionally, a very important concern against discussed form of voting is the fear that it divides society into two parts. The first group is enjoying the convenience of e-voting and the second one does not have the access to the Internet. What is more, one should remember that older generations may not be comfortable with using the system. Such situations may create a division into those skilled and knowledgeable citizens on the one side and those worse equipped and unskilled on the other. It may result in a growing gap of participation. This

\footnotetext{
29 J. Gerlach, U. Gasser, Three Case Studies from Switzerland: E-Voting, Berkman Center Research Publication, No. 03.01/2009, p. 5.
} 
phenomenon is known as a 'digital divide' and it may be an important issue strengthening welfare differences in geographical regions.

A very significant concern about e-vote is voters' authentication. Because today there is no universally available form of digital identification, it is practically impossible to ensure that voters who are voting remotely over the Internet are really who they say they are. On one hand it has to be said that passwords and digital signatures can help, but on the other - they can be shared among voters. ${ }^{30}$ With electronic voting system many technical problems may occur. The voting systems based on the use of ICT are vulnerable to attacks both on the central e-voting servers and on each private voter's computer. These attacks may lead undoubtedly to the disruption of the voting process and may bring the final results of voting into question. That is why the servers, systems and the computers or the kiosks should be secured so that they cannot be tampered with or infected with viruses. ${ }^{31}$ Furthermore, one of the reasons for delays in introducing advanced voting technologies is almost unanimous carefulness among societies of information sciences regarding the so-called Internet-based elections. ${ }^{32}$ Many countries resigned from $e$-voting because they found it too risky. Other nations do not seem to realize the advantages of electronic voting over traditional way of election - by ballot boxes.

\section{EXAMPLES OF ELECTRONIC VOTING EXPERIENCES IN EUROPE}

Electronic voting is already in use in many countries all over the world and has proven to speed up the counting of votes as well as improve turnout among disabled voters. Undoubtedly, the undisputed leader among countries where e-voting systems has been introduced are the United States. But also in many European countries, new voting technologies have

\footnotetext{
30 Online Voting..., op.cit., p. 4.

31 Ibidem.

32 Ch. O'Hanlon, A Conversation with Douglas W. Jones and Peter G. Neumann, Queue 4, 9/2006, pp. 16-23, http://queue.acm.org/detail.cfm?id=1180188, (5.06.2009).
} 
Table-1: Application of electronic voting in the European countries

\begin{tabular}{|l|l|l|}
\hline Country & Application of e-voting & time \\
\hline Austria & Test Election for Austrians living abroad & $12-14.10 .2006$ \\
\hline Belgium & Voting machines - tests & No date \\
\hline Bulgaria & Town Council E-Voting of Kazanluk & 07.05 .2008 \\
\hline Estonia & Municipal elections & $10-12.10 .2005$ \\
\hline Estonia & Parliamentary elections & $26-28.02 .2007$ \\
\hline Finland & $\begin{array}{l}\text { E-voting in local elections in Karkkila, } \\
\text { Kaunianien, Vihti }\end{array}$ & 10.2008 \\
\hline Italy & $\begin{array}{l}\text { Administration elections - Autonomous Province } \\
\text { of Trento }\end{array}$ & 08.05 .2005 \\
\hline the Netherlands & Parliamentary elections - Lower House & $18-22.11 .2006$ \\
\hline Portugal & Parliamentary General Elections - Voters Abroad & 20.02 .2005 \\
\hline Portugal & Elections for the European Parliament & 06.2004 \\
\hline Spain & $\begin{array}{l}\text { Referendum „Constitution for Europe”- 53 } \\
\text { municipalities }\end{array}$ & $01-18.02 .2005$ \\
\hline Great Britain & Local elections (Liverpool, Sheffield...) & $2003,2005,2007$ \\
\hline Switzerland & $\begin{array}{l}\text { Neuenburg, Zurich, Geneva (February 2009 } \\
\text { Constitution) }\end{array}$ & $\begin{array}{l}\text { from 2001 - ... } \\
\text { test voting }\end{array}$ \\
\hline
\end{tabular}

Source: Competence Center for Electronic Voting and Participation (E-Voting.CC).

been implemented or their implementation is in progress. On the local level electronic voting with the Internet, text messages and with the use of modified interactive kiosks and smart cards ${ }^{33}$ was firstly introduced in spring 2002 in Great Britain, in two electoral districts in Liverpool and three in Sheffield. Other attempts to put into practice the e-voting lead to various effects in different countries. Examples of e-voting attemts are presented in Table 1.

The most successful attempts related to introduction of e-votings are associated with the electronic voting systems from Switzerland and Estonia.

33 Which were used to identify voters in a kiosk. 
In Switzerland, the process of testing and implementation of three pilot voting projects (that included cantons of Geneva, Zurich and Neuchâtel) was initiated already in the year 2000. Firstly, a federal decision has been made, then communes and cantons were supposed to individually decide about the project. The Swiss pilot projects are based on various applications of the new technologies: the Internet or text messages.

The fundamental aim of implementation of e-voting systems in Switzerland was to provide additional platform that would enable voting in referenda and elections (particularly for the disabled people and the Swiss living abroad) and allow to put the so-called digital signatures when submitting proposal connected with an initiative, referendum or election. The Swiss do not mean to replace current manners of voting (by ballot boxes or by mail) but their aim is to guarantee additional solution that would result in a higher voter turnout. The most important group of voters, who would be mostly interested in the implementation of e-voting, are young people that use the Internet (they usually did not participate in previous elections), the Swiss who live away from their home county and each voter who is not capable of participating in elections due to physical disabilities, for example.

The second European example of electronic voting introduction is Estonia which happened to be the first country in the world that conducted internet voting. The most important reasons for introducing this new way of voting in Estonia are : to make additional and convenient voting channel available and consequently to update voting procedures, and enable more efficient use of infrastructure (digital platforms and electronic IDs). Estonian e-voting system differs then from Swiss projects. In order to vote via the Internet, a voter needs: electronic identity card (eID) with valid certificates (renewed at a webpage), PIN numbers (issued together with eID cards) and a computer with eID card reader (plus an appropriate software available at installer.id.ee/), internet connection and one of the following operating systems installed: Windows, MacOS, Linux. ${ }^{34}$ Researches on applications and efficiency of $e$-voting in Estonia report that Estonians' attitude towards this new form of voting was and still is positive,

\footnotetext{
34 Estonian National Electoral Committee.
} 
and decision to seize the opportunity to i-vote seems to be dependent on confidence in the new method and not - as it was previously expected - on political influences.

\title{
CONCLUSIONS
}

Opportunities exist for research, tests, and experimentation in the field of employing new forms in democratic processes in the political market. One of the most important tools of e-democracy and one of the most important democratic procedure is electronic voting. Recent years prove that interest in implementation of new forms of voting participation increases systematically, especially in Europe. It is confirmed by various pilot projects introduced in greater and greater number of countries whose parliaments consider the idea of electronic voting implementation. Motives for $e$-voting implementation are various, and the most frequent reasons are as follows: increasing voters' mobility, enabling voters who live outside their home country to participate in elections, increasing voter turnout by providing additional platform for voting, extending access to democratic procedures for the sick and disabled people, decreasing costs of elections, publishing election results in an independent and much quicker way. Despite apparent problems concerning worries about safe and secure elections etc., positive experience of increasingly higher number of European countries may act as a spur to implementation of e-voting not only in the rest of European nations, but also in many countries all over the world.

\begin{abstract}
The newly used word e-democracy is an evidence that modern technologies have also been widely used in politics. The main subject of this text is to analyze the electronic voting (e-voting) as one of the forms of electronic democracy. The article attempts to answer the following research questions: First, what is the impact of ICT on the political processes in the
\end{abstract}


political market - particularly on the voting procedures? Secondly, what is the essence of electronic voting and what are its main features? Finally, what are the advantages and concerns related to the e-voting systems? Theoretical considerations are based mainly on the concept of electronic democracy constructed by Martin Hagen, while in the final part some European experiences related to the use of e-voting are mentioned. 